\title{
Penentuan Error Dalam Peramalan Jumlah Korban Demam Berdarah Dengue Menggunakan Metode Neural Network (Kasus : Rumah Sakit Charitas Palembang)
}

\author{
Maria Bellaniar Ismiati ${ }^{1}$, Latius Hermawan ${ }^{2}$ \\ Program Studi Sistem Informasi dan Informatika \\ Fakultas Sains dan Teknologi \\ Universitas Katolik Musi Charitas Palembang \\ Jalan Bangau No.60 Palembang-30113 \\ 1.choibella89@gmail.com, ㄹtiuz.hermawan@gmail.com
}

\begin{abstract}
Demam Berdarah Dengue (DBD) merupakan jenis penyakit yang menduduki peringkat pertama di ASEAN serta peringkat kedua di dunia. Jumlah korban DBD di RS Charitas Palembang cenderung meningkat pada bulan-bulan tertentu dan tidak menentu setiap bulannya. Selain itu, data korban DBD tersebut tidak dijadikan bahan evaluasi untuk menekan jumlah korban tersebut. Hal tersebut menjadi dasar untuk melakukan peramalan jumlah korban DBD pada tahun berikutnya. Penelitian untuk meramalkan jumlah korban DBD sudah pernah dilakukan dengan berbagai teknik kecerdasan buatan. Penelitian yang dilakukan sekarang menggunakan data RS Charitas Palembang yang berpola time series selama 10 tahun terakhir dengan menggunakan metode Neural Network. Hasil yang didapatkan adalah pola korban DBD mulai signifikan pada bulan Desember kemudian mencapai puncak pada bulan Januari, disertai angka peramalan pada masing-masing bulan pada tahun berikutnya. Selanjutnya penghitungan error menggunakan Neural Network didapatkan dengan menggunakan input layer 12, hidden neuron 28, dan output layer 1 serta error yang didapatkan $12,59 \%$.
\end{abstract}

Keywords - Demam berdarah, peramalan, Neural Network, error

\section{PENDAHULUAN}

Penyakit Demam Berdarah Dengue (DBD) masih merupakan salah satu masalah kesehatan masyarakat yang utama di Indonesia. Data dari seluruh dunia menunjukkan Asia menempati urutan pertama dalam jumlah penderita DBD setiap tahunnya. Sementara itu, terhitung sejak tahun 1968 hingga tahun 2009, World Health Organization (WHO) mencatat Indonesia sebagai negara dengan kasus DBD tertinggi di Asia Tenggara (Sukowati, 2010). Selain itu, berdasarkan data Rumah Sakit Charitas Palembang, jumlah penderita penyakit DBD cenderung meningkat dari tahun ke tahun pada bulan-bulan tertentu. Hal tersebut terjadi karena kurangnya pengetahuan masyarakat tentang kapan waktu/bulan yang berpotensi terjadinya DBD, khususnya pada masyarakat Palembang. Faktor penyebab lainnya adalah kurangnya kesadaran masyarakat dalam mencegah timbulnya penyakit DBD tersebut.

Jumlah penderita penyakit DBD terus meningkat dari tahun ke tahun dikarenakan adanya ketidakpastian jumlah penderita penyakit tersebut dari tahun ke tahun. Untuk menyelesaikan masalah di masa depan yang tidak dapat dipastikan, orangorang senantiasa berupaya menyelesaikannya dengan model pendekatan-pendekatan yang sesuai dengan perilaku aktual data yang ada, termasuk dalam melakukan peramalan. Peramalan tersebut memerlukan perencanaan dan penjadwalan dari data-data masa lampau dalam menentukan perkiraan hasil yang akurat. Data yang akan digunakan merupakan data bulanan dari Januari hingga Desember dalam mendukung peramalan untuk menentukan perkiraan jumlah penderita DBD pada time series. Time series yang digunakan akan diambil dari RS Charitas Palembang, yaitu dalam jangka waktu 10 tahun terakhir.

Peramalan DBD telah banyak dilakukan di berbagai Negara seperti China, Bangladesh, India 
dengan menggunakan beberapa metode peramalan yang ada. Salah satu contoh metode peramalan yang telah digunakan sebelumnya adalah Neural Network yang merupakan bagian dari artificial model. Berdasarkan penelitian-penelitian sebelumnya, Neural Network yang merupakan artificial model lebih menampilkan penelitian berupa trial and error dari perubahan learning rate, momentum, maksimum iterasi, fungsi aktivasi bahkan pencarian nilai error dari neural network sendiri. Oleh karena itu, Neural Network melakukan proses pembelajaran beberapa kali hingga didapatkan nilai error yang paling rendah.

\section{LANDASAN TEORI}

Menurut (Jay dan Render, 2006), peramalan/forecasting adalah seni dan ilmu yang memprediksi peristiwa-peristiwa masa depan dengan menggunakan data historis dan memproyeksikannya ke masa depan dengan menggunakan beberapa bentuk model matematis. Tujuan dari peramalan adalah untuk memperoleh informasi mengenai perubahan yang akan terjadi di masa depan dan selanjutnya akan berpengaruh terhadap implementasi kebijakan serta konsekuensinya. Peramalan terhadap sesuatu tidak akan pernah tepat $100 \%$ karena masa depan mempunyai masalah ketidakpastian. Namun demikian, dengan memilih metode yang tepat, peramalan dapat mempunyai tingkat kesalahan yang kecil atau dapat memberikan hasil di masa depan yang mendekati data aktual. Hasil dari peramalan ini menjadi dasar dalam membuat suatu rencana yang akan diwujudkan sebagai bahan penjabaran rencana di masa depan. Data dalam penelitian ini menggunakan data korban DBD di RS Charitas Palembang.

Penyakit DBD adalah penyakit yang ditularkan oleh gigitan nyamuk Aedes aegypti dan Aedes albopictus yang terinfeksi virus dengue. Wabah DBD pertama kali terjadi di Manila pada tahun 1953-1954 yang disertai pendarahan saluran cerna. Selain itu, di Indonesia ditemukan di Surabaya pada tahun 1968. Pada tahun 1980, seluruh propinsi di Indonesia kecuali Timor Timur telah terjangkit penyakit ini. Sejak pertama kali ditemukan, jumlah kasus menunjukkan kecenderungan yang meningkat, baik dalam jumlah kasusnya maupun luas wilayah yang terjangkit dan secara sporadis selalu terjadi Kejadian Luar Biasa (KLB) setiap tahunnya (Soepardi, 2010). Penyakit DBD digunakan sebagai data karena data korban DBD yang dirawat inap merupakan salah satu contoh data time series.

Menurut Boediono, time series atau data berkala adalah data yang dikumpulkan dari waktu ke waktu untuk menggambarkan suatu perkembangan/ kecenderungan suatu peristiwa. Selain itu, data berkala atau time series merupakan serangkaian pengamatan terhadap suatu peristiwa, kejadian, gejala ataupun variabel yang diambil dari waktu ke waktu, yang kemudian dicatat secara teliti menurut urutan waktu terjadinya dan disusun sebagai data statistik. (Sofjan, 2004).

Neural Network adalah sistem pemosesan informasi yang memiliki karakteristik mirip dengan jaringan syaraf biologi. Neural Network yang sederhana pertama kali diperkenalkan oleh McCulloch dan Pitts di tahun 1943. McCulloch dan Pitts menyimpulkan bahwa kombinasi beberapa neuron sederhna menjadi sebuah sistem neural akan meningkatkan kemampuan komputasinya. Selanjutnya pada tahun 1958, Rosenblatt memperkenalkan dan mulai mengembangkan model jaringan yang disebut Perceptron. Metode pelatihan tersebut diperkenalkan untuk mengoptimalkan hasil iterasinya.

Dengan meniru sistem jaringan biologis, maka sistem Neural Network memiliki 3 karakteristik utama menurut (Siang, 2005), yaitu:

1.Arsitektur jaringan

Merupakan pola keterhubungan antara neuron yang membentuk suatu jaringan.

\section{Algoritme jaringan}

Merupakan metode untuk menentukan nilai bobot hubungan. Terdapat dua jenis metode, yaitu pelatihan atau pembelajaran (memorisasi) dan metode pengenalan atau aplikasi. 


\section{Fungsi aktivasi}

Merupakan fungsi untuk menentukan nilai keluaran berdasarkan nilai total masukan pada neuron. Fungsi aktivasi suatu algoritme jaringan dapat berbeda dengan fungsi aktivasi algoritme jaringan lain.

Zaitun Time Series adalah aplikasi yang didesain untuk membantu perhitungan analisis statistik pada time series. Aplikasi ini menyediakan cara yang mudah dalam pemodelan dan peramalan time series. Zaitun Time Series menyediakan berbagai perhitungan analisis statistik seperti Trend Analysis, Decomposition, Moving Average, Linear Regression, Exponential Smoothing, Correlogram dan Neural Network. Zaitun Time Series pada awalnya dikembangkan oleh tim "Time series" sebagai tugas akhir pada jenjang pendidikan DIV di Sekolah Tinggi Ilmu Statistik Jakarta, Indonesia. Saat ini, Zaitun Time Series dikembangkan lebih lanjut oleh tim pengembang di zaitunsoftware.com. Zaitun Time Series adalah aplikasi yang bebas (free), dan tanpa garansi (no warranty) (Wirawan, 2012).

\section{METODE PENELITIAN}

Model penelitian yang digunakan menggunakan metode Neural Network yang merupakan bagian dari salah satu metode di artificial model.

\section{Arsitektur Neural Network}

Secara umum, arsitektur Neural Network terdiri atas beberapa lapisan, yaitu lapisan masukan (input layer), lapisan tersembunyi (hidden layer), dan lapisan keluaran (output layer). Masing-masing lapisan mempunyai jumlah node atau neuron yang berbeda-beda.

Arsitektur Neural Network tersebut dapat diilustrasikan seperti pada gambar berikut ini :

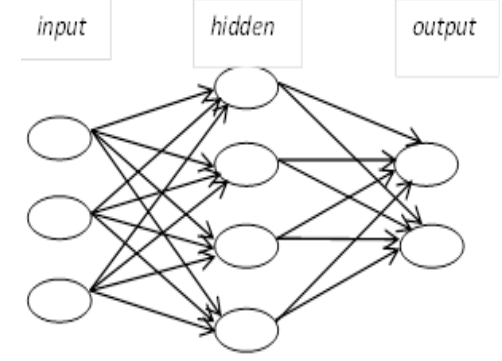

Gambar 1. Arsitektur Neural Network
1.Lapisan masukan (input layer)

Lapisan masukan merupakan lapisan yang terdiri dari beberapa neuron yang akan menerima sinyal dari luar dan kemudian meneruskan ke neuron-neuron lain dalam jaringan.

2.Lapisan tersembunyi (hidden layer)

Lapisan tersembunyi berfungsi meningkatkan kemampuan jaringan dalam memecahkan masalah.

3.Lapisan keluaran (output layer)

Lapisan keluaran berfungsi menyampaikan sinyal-sinyal keluaran hasil pemrosesan jaringan. Lapisan ini juga terdiri dari sejumlah neuron. (Siang, 2005).

2. Input Layer

Jumlah data dalam satu periode digunakan sebagai jumlah masukan dalam Neural Network. Pada data bulanan dengan periode satu tahun, maka masukan Neural Network yang dipakai terdiri dari 12 masukan (Rosadi, 2011).

3. Hidden Layer

Dalam menentukan hidden layer, dilakukan dengan trial and error untuk mendapatkan suatu nilai peramalan. Dalam penelitian ini akan menggunakan teori dari Rosadi, 2011, yaitu penentuan hidden layer dilakukan dengan beberapa kali percobaan yang dimulai dari layer satu atau terkecil kemudian dilanjutkan hingga sesuai dengan input layer. Semakin banyak jumlah lapisan tersembunyi diharapkan jaringan akan memberikan hasil yang lebih akurat, tetapi proses pelatihannya lebih runut dan butuh waktu lama.

4. Output Layer

Dalam menentukan output layer, disesuaikan dengan data yang akan dianalisis dengan periode waktu yang digunakan. Pada peramalan time series, output atau keluarannya adalah satu, yaitu berupa nilai peramalannya sendiri. (Rosadi, 2011).

5. Learning Rate

Laju pemahaman (learning rate) merupakan suatu konstanta yang dipakai dalam seluruh iterasinya. Kecepatan iterasi ditentukan pula oleh laju pemahaman $(=\alpha$ dengan $0 \leq \alpha \leq 1$ ) yang dipakai. Semakin 
besar harga $\alpha$, semakin sedikit iterasi yang diperlukan. Akan tetapi jika $\alpha$ terlalu besar, maka akan merusak pola yang sudah benar sehingga pemahaman menjadi lambat (Rosadi \& Siang, 2011 \& 2005).

6. Momentum

Penambahan momentum dimaksudkan untuk menghindari perubahan bobot yang mencolok akibat adanya data yang sangat berbeda dengan yang lain (outlier). Range yang dapat dipilih untuk momentum adalah dari 0 hingga 1 (Rosadi, 2011).

\section{Fungsi Aktivasi}

Fungsi aktivasi yang dipakai harus memenuhi beberapa syarat, yaitu kontinu dan merupakan fungsi yang tidak turun. Salah satu fungsi yang memenuhi kedua syarat tersebut sehingga sering dipakai adalah fungsi sigmoid biner dan bipolar. Fungsi sigmoid biner memiliki range $(0,1)$ sedangkan sigmoid bipolar memiliki range (-1,1) (Rosadi, 2011).

8. Lama Iterasi

Jaringan dapat dilatih terus menerus sehingga semua pola pelatihan dikenali dengan benar. Akan tetapi hal itu tidak menjamin jaringan akan mampu mengenali pola pengujian dengan tepat. Umumnya data dibagi menjadi 2 bagian, yaitu pola data untuk yang dipakai sebagai pelatihan dan data yang dipakai untuk pengujian. Perubahan bobot dilakukan berdasarkan pola pelatihan. Akan tetapi selama pelatihan (contohnya setiap 10 epoch), kesalahan yang terjadi dihitung berdasarkan semua data (pelatihan dan pengujian). Selama kesalahan itu menurun, pelatihan terus dijalankan. Akan tetapi jika kesalahannya sudah meningkat, pelatihan tidak ada gunanya untuk diteruskan lagi. (Rosadi \& Siang, $2011 \& 2005)$.

\section{HASIL DAN PEMBAHASAN}

\section{A. Teknik Pengumpulan dan Sumber Data}

Bahan yang digunakan adalah sekumpulan time series korban DBD yang diambil dari RS Charitas Palembang selama 10 tahun terakhir (2003-2012). Data yang dikumpulkan merupakan data primer yang diambil langsung di RS Charitas Palembang selama kurang lebih 3 bulan seperti pada Tabel 1 berikut.

TABEL 1. LAPORAN PASIEN DBD RAWAT INAP TAHUN $2003-2012$

\begin{tabular}{|c|c|c|c|c|c|c|c|c|c|c|}
\hline \multirow{2}{*}{ Bulan } & \multicolumn{10}{|c|}{ Tahun (20') } \\
\hline & 03 & 04 & 05 & 06 & 07 & 08 & 09 & 10 & 11 & 12 \\
\hline \multirow{2}{*}{$\begin{array}{l}\text { Janu } \\
\text { ari }\end{array}$} & 26 & & 15 & 12 & 32 & 17 & 25 & 15 & & 36 \\
\hline & 3 & 53 & 9 & 0 & 8 & 4 & 7 & 5 & 51 & 1 \\
\hline \multirow{2}{*}{$\begin{array}{l}\text { Febr } \\
\text { uari }\end{array}$} & 20 & & 11 & 14 & 40 & 20 & 14 & 12 & & 26 \\
\hline & 4 & 83 & 9 & 2 & 8 & 5 & 4 & 6 & 46 & 8 \\
\hline \multirow{2}{*}{$\begin{array}{l}\text { Mar } \\
\text { et }\end{array}$} & 16 & 15 & 10 & 15 & 19 & 12 & 14 & 12 & & 21 \\
\hline & 6 & 4 & 0 & 0 & 3 & 3 & 1 & 5 & 55 & 7 \\
\hline \multirow{2}{*}{ April } & & & & 11 & 16 & 14 & & 10 & & 17 \\
\hline & 82 & 89 & 58 & 3 & 9 & 8 & 89 & 2 & 79 & 9 \\
\hline \multirow{2}{*}{ Mei } & & & & 13 & 16 & 17 & & & & 12 \\
\hline & 81 & 52 & 68 & 7 & 3 & 6 & 78 & 88 & 75 & 6 \\
\hline \multirow[b]{2}{*}{ Juni } & & & & 11 & 12 & 11 & & & & 10 \\
\hline & 40 & 40 & 43 & 2 & 7 & 9 & 56 & 78 & 99 & 5 \\
\hline \multirow{2}{*}{ Juli } & & & & 12 & 10 & & & & 10 & \\
\hline & 33 & 37 & 37 & 6 & 0 & 79 & 55 & 59 & 7 & 88 \\
\hline \multirow{2}{*}{$\begin{array}{l}\text { Agus } \\
\text { tus }\end{array}$} & & & & 10 & & & & & & \\
\hline & 22 & 39 & 48 & 8 & 50 & 89 & 41 & 46 & 69 & 82 \\
\hline \multirow{2}{*}{$\begin{array}{l}\text { Sept } \\
\text { em- } \\
\text { ber }\end{array}$} & & & & 10 & & 11 & & & & \\
\hline & 29 & 46 & 44 & 2 & 56 & 7 & 43 & 62 & 80 & 36 \\
\hline $\begin{array}{l}\text { Okto } \\
\text { ber }\end{array}$ & 35 & 28 & 54 & 95 & 47 & $\begin{array}{l}12 \\
3\end{array}$ & 53 & 66 & 52 & 38 \\
\hline \multirow{3}{*}{$\begin{array}{l}\text { Nov } \\
\text { em- } \\
\text { ber }\end{array}$} & & & & & & & & & & \\
\hline & & & & 10 & & 17 & & & 12 & \\
\hline & 50 & 54 & 55 & 6 & 52 & 9 & 86 & 49 & 2 & 41 \\
\hline \multirow{3}{*}{$\begin{array}{l}\text { Des } \\
\text { em- } \\
\text { ber }\end{array}$} & & & & & & & & & & \\
\hline & & & & 20 & 13 & 26 & 14 & & 26 & \\
\hline & 79 & 98 & 80 & 2 & 9 & 5 & 1 & 57 & 0 & 75 \\
\hline \multirow{2}{*}{$\begin{array}{l}\text { Juml } \\
\text { ah }\end{array}$} & 10 & 77 & 86 & 15 & 18 & 17 & 11 & 10 & 10 & 16 \\
\hline & 84 & 3 & 5 & 13 & 32 & 97 & 84 & 13 & 95 & 16 \\
\hline
\end{tabular}

Data yang diambil berupa data masa lampau selama 10 tahun terakhir dimulai dari 2003 hingga 2012. Pengambilan data dilakukan di RS Charitas Palembang selama sekitar 2 bulan. Penggunaan metode Neural Network dilakukan dengan menggunakan perangkat lunak Zaitun Time series untuk mendapatkan hasil peramalan serta error yang dihasilkan. Zaitun Time Series merupakan software yang memang dikhususkan untuk menghitung angka peramalan dari metode Neural Network.

\section{B. Analisis Data}

Dalam penelitian ini, analisis data dilakukan untuk melihat bulan-bulan apa saja yang signifikan tiap tahunnya dengan menggunakan grafik yang 
didapat dari Microsoft Excel. Hal tersebut dilakukan agar dapat disesuaikan dengan hasil peramalan yang nanti didapat. Di sisi lain adalah untuk membuktikan apakah data tersebut mengandung faktor seasonal (musiman) atau tidak sehingga dapat ditentukan metode yang sesuai dengan masalah dan data yang ada. Setelah mendapatkan bulan-bulan yang signifikan dan pola musiman yang mungkin didapat, akan langsung dilakukan analisis data menggunakan metode Neural Network.

TABEL 2. TREND BULAN YANG BERPOTENSI DBD SETIAP TAHUN

\begin{tabular}{|l|l|}
\hline Tahun & Bulan yang berpotensi terjadi DBD \\
\hline 2003 & Januari, Februari, Maret \\
\hline 2004 & Maret, Desember, April \\
\hline 2005 & Januari, Februari, Maret \\
\hline 2006 & Desember, Februari, Maret \\
\hline 2007 & Februari, Januari, Maret \\
\hline 2008 & Desember, November, Februari \\
\hline 2009 & Januari, Februari, Maret, Desember \\
\hline 2010 & Januari, Februari, Maret \\
\hline 2011 & Desember, November, Juli \\
\hline 2012 & Januari, Februari, Maret \\
\hline
\end{tabular}

\section{Pembahasan Hasil Penelitian}

Hasil analisis time series yang didapat adalah berdasarkan Tabel 2, yaitu bulan-bulan yang berpotensi terjadi wabah DBD adalah Januari (menjadi bulan tertinggi sebanyak 6 kali dalam 10 tahun terakhir), Februari (menjadi bulan tertinggi sebanyak 8 kali dalam 10 tahun terakhir), dan Maret (menjadi bulan tertinggi sebanyak 8 kali dalam 10 tahun terakhir). Peramalan DBD menggunakan neural network dilakukan dengan menggunakan software Zaitun Time series yang dapat melakukan pemodelan neural network terhadap sebuah variabel time series. Penjabaran pemodelan neural network dilakukan melalui beberapa iterasi (maksimum 10000 iterasi) dan perulangan perhitungan sebanyak 10 kali.

Arsitektur jaringan yang dibentuk dari proses perhitungan peramalan DBD ini didasarkan pada hasil iterasi dari software Zaitun Time series. Setelah Zaitun Time series selesai melakukan iterasi, tidak diberikan gambar arsitekturnya sehingga arsitektur jaringan digambarkan secara manual berdasarkan nilai error yang terkecil. Dalam mendapatkan gambar arsitektur jaringannya, dilakukan beberapa kali perubahan dan percobaan pada hidden neuron yang didapat dari teori mengenai Neural Network.

Dalam melakukan proses iterasi, semua parameter perhitungan menggunakan default dari Zaitun Time series. Parameter perhitungan tersebut adalah output 1 , learning rate 0,05 , momentum 0,5 , maksimum iterasi 10000 , fungsi aktivasi Bipolar sigmoid yang ditentukan dengan beberapa percobaan. Walaupun menggunakan default dari Zaitun Time series, hasil perhitungan juga disesuaikan dengan hasil iterasi dan error yang didapatkan. Inti dari proses iterasi neural network dalam penelitian ini adalah pada trial and error melalui 10 kali percobaan hingga didapatkan nilai error yang paling kecil.

Dalam kasus ini, yang dimaksud output 1 adalah merupakan nilai peramalannya yang berupa suatu himpunan, yaitu nilai peramalan dimulai dari bulan Januari 2013 hingga Desember 2014. Selanjutnya untuk menentukan nilai dari learning rate dan momentum dapat dilakukan trial and error. Berdasarkan beberapa referensi yang telah dibaca, range yang dapat digunakan adalah dimulai dari 0 hingga 1 . Maksimum iterasi yang digunakan adalah 10000 karena apabila iterasi yang digunakan semakin sedikit, maka proses pembelajaran yang dilakukan akan semakin sedikit pula untuk mendekati nilai error yang rendah. Yang terakhir adalah fungsi aktivasi yang digunakan, yaitu Bipolar Sigmoid karena fungsi aktivasi yang digunakan harus kontinu dan merupakan fungsi yang tidak turun serta apabila nilai output yang diharapkan tidak berupa negatif, maka digunakan fungsi Sigmoid. Dalam percobaan yang dilakukan dengan menggunakan kedua fungsi tersebut, yang lebih mendekati adalah Bipolar Sigmoid dengan nilai error yang lebih rendah apabila dibandingkan dengan fungsi aktivasi Sigmoid Biner. 
Contoh salah satu hasil perhitungan dari beberapa iterasi yang dilakukan oleh Zaitun Time series ada pada Gambar 9.

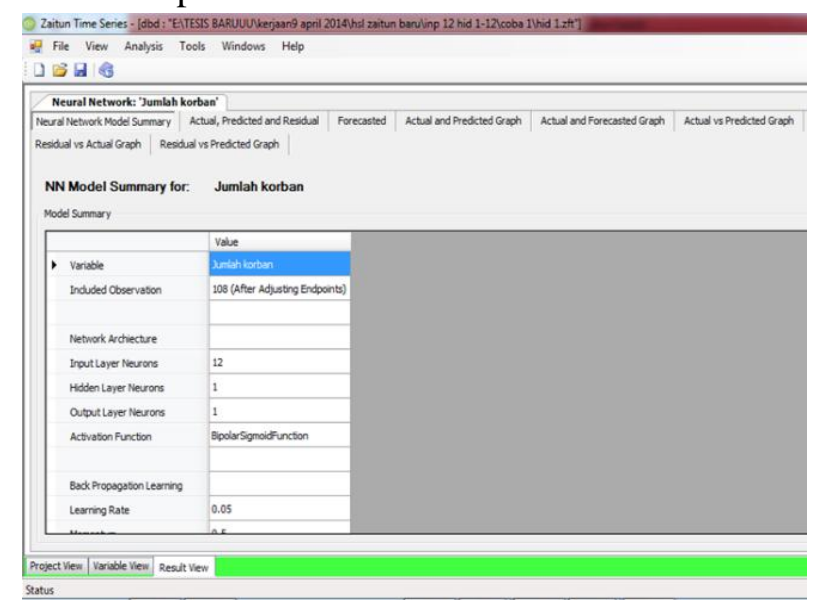

Gambar 9. Tampilan perhitungan Neural Network Zaitun Time Series

Dari semua kombinasi yang didapatkan, selanjutnya dilakukan proses perhitungan nilai error dengan menggunakan rumus MAPE. Hasil lengkap nilai error untuk masing-masing kombinasi tersebut ada pada Tabel 3.

TABEL 3. HASIL ERROR YANG DIHASILKAN DARI MASING-MASING PERCOBAAN DENGAN INPUT, HIDDEN NEURON, DAN OUTPUT YANG SAMA (MAPE DALAM \%)

\begin{tabular}{|l|l|l|l|l|l|}
\hline $\begin{array}{l}\text { Hidden } \\
\text { layer }\end{array}$ & Coba 1 & Coba 2 & Coba 3 & Coba 4 & Coba 5 \\
\hline 1 & 28,76 & 28,76 & 28,76 & 28,76 & 28,76 \\
\hline 2 & 23,56 & 23,43 & 23,36 & 23,37 & 29,04 \\
\hline 3 & 20,30 & 20,06 & 19,77 & 23,02 & 23,43 \\
\hline 4 & 18,38 & 22,84 & 20,71 & 19,20 & 18,92 \\
\hline 5 & 16,73 & 16,21 & 16,41 & 20,92 & 17,27 \\
\hline 6 & 18,31 & 19,69 & 20,69 & 17,06 & 19,86 \\
\hline 7 & 16,79 & 15,59 & 17,99 & 15,22 & 16,41 \\
\hline 8 & 16,21 & 18,27 & 16,05 & 17,08 & 16,12 \\
\hline 9 & 16,65 & 13,89 & 14,68 & 17,64 & 15,77 \\
\hline 10 & 18,10 & 16,96 & 14,97 & 15,61 & 16,72 \\
\hline 11 & 17,65 & 16,69 & 15,08 & 14,03 & 17,51 \\
\hline 12 & 16,07 & 15,99 & 15,03 & 16,44 & 14,97 \\
\hline 17 & 14,79 & 14,45 & 15,11 & 13,59 & 13,56 \\
\hline 18 & 13,21 & 15,06 & 15,53 & 13,85 & 14,61 \\
\hline 19 & 14,22 & 13,52 & 13,63 & 16,12 & 15,81 \\
\hline 20 & 13,87 & 13,78 & 12,80 & 14,37 & 15,11 \\
\hline 21 & 13,91 & 13,60 & 15,39 & 13,89 & 14,32 \\
\hline 22 & 15,02 & 14,95 & 14,39 & 15,50 & 15,80 \\
\hline 23 & 14,14 & 14,46 & 14,14 & 13,50 & 16,43 \\
\hline 24 & 18,17 & 14,96 & 14,51 & 13,34 & 12,79 \\
\hline 25 & 15,45 & 13,25 & 13,74 & 14,49 & 13,91 \\
\hline 26 & 13,22 & 14,05 & 13,08 & 15,21 & 14,08 \\
\hline 27 & 13,66 & 14,55 & 15,49 & 13,32 & 13,86 \\
\hline 28 & 15,12 & 12,59 & 13,27 & 14,89 & 15,63 \\
\hline & & & & & \\
\hline
\end{tabular}

Nilai error yang didapatkan dari Tabel 3 merupakan hasil trial and error dari 5 kali percobaan dengan hidden neuron yang berubahubah. Hasil tersebut didapatkan dari nilai MAPE dengan penjelasan sebagai berikut. Mean Absolute Percentage Error (MAPE) dihitung dengan menggunakan kesalahan absolut pada tiap periode dibagi dengan nilai observasi yang aktual untuk periode itu. Selanjutnya, merata-rata kesalahan persentase absolut tersebut. Pendekatan ini berguna ketika ukuran atau besar variabel ramalan itu penting dalam mengevaluasi ketepatan ramalan. MAPE mengindikasikan seberapa besar kesalahan dalam meramal dengan membandingkan nilai aktual pada deret. Metode MAPE digunakan jika nilai Yt besar. MAPE juga merupakan nilai indikator yang biasa digunakan untuk menunjukkan performance atau keakuratan pada hasil proses peramalan. MAPE dapat dihitung dengan rumus sebagai berikut.

$$
\text { MAPE }=\text { MAPE }=\frac{1}{n} \sum_{t=1}^{n}|P E t|
$$

Bagian dari keputusan untuk menggunakan teknik peramalan tertentu melibatkan penentuan apakah teknik ini akan menghasilkan kesalahan peramalan yang dinilai cukup kecil. Metode khusus yang digunakan dalam peramalan meliputi perbandingan metode mana yang akan menghasilkan kesalahan-kesalahan peramalan yang cukup kecil. Metode ini baik untuk memprediksi metode peramalan sehingga menghasilkan kesalahan ramalan yang relatif kecil. Fungsi dari perhitungan ketepatan peramalan adalah untuk membandingkan ketepatan dua atau lebih metode yang berbeda, sebagai alat ukur apakah teknik yang diambil dapat dipercaya atau tidak, serta untuk membantu mencari sebuah metode yang optimal atau metode yang lebih sesuai dengan data yang ada

Microsoft Excel digunakan untuk mengolah proses perhitungannya. Dalam mendapatkan berbagai error tersebut, dilakukan proses perulangan selama beberapa kali hingga error yang didapatkan per masing-masing percobaan mulai menaik. Inti dari proses perhitungan error tersebut adalah ketika error yang didapat di percobaan selanjutnya masih menurun, proses pembelajaran akan terus dilanjutkan hingga error pada percobaan selanjutnya menaik. Seperti pada Tabel 3, pada percobaan ke-2 di neuron ke-28 telah mendapatkan error yang relatif kecil yaitu 
12,59\% dan ketika dilanjutkan ke percobaanpercobaan selanjutnya, nilai error tersebut semakin naik sehingga proses pembelajaran dihentikan hingga percobaan ke-5.

Pada Tabel 3, bahwa ada perubahan nilai error di masing-masing neuron pada arsitektur Neural Network dimulai dari hidden neuron 1 hingga 12 dan hidden neuron 17 hingga 28. Pemilihan hidden neuron 1 hingga 12 didasarkan pada referensi yang telah dipaparkan di Bab 2 atau 3, yaitu dicoba dari neuron 1 hingga neuron yang sesuai dengan jumlah input-nya satu per satu. Di lain sisi, hidden neuron 17 hingga 28 dipilih berdasarkan Skapura dengan rumus yang ada di Bab 3, yaitu minimum hidden neuron adalah 17/18 diteruskan hingga error di masing-masing hidden neuron selanjutnya naik.

Percobaan dalam penentuan error di masingmasing hidden neuron dapat terlihat bahwa dengan semakin banyak neuron maka hasil error-nya semakin rendah, contohnya pada neuron ke-28 nilai error yang didapatkan adalah $12,59 \%$. Pada percobaan pertama di hidden neuron 1, error yang didapatkan adalah sekitar $28,76 \%$ dan mengalami penurunan serta kenaikan hingga hidden neuron 12 dengan nilai error sekitar 16,07\%. Selanjutnya berdasarkan Skapura, saat dimulai dari hidden neuron ke-1, error yang didapatkan adalah sekitar $14,79 \%$ dan mengalami penurunan serta kenaikan hingga hidden neuron 28 dengan nilai error sekitar 13,21\%. Apabila dibandingkan nilai error di neuron yang cenderung sedikit dengan yang banyak, lebih rendah error yang ada pada neuron 17 hingga 28. Hal tersebut dikarenakan proses pembelajaran akan lebih lengkap dan mendalam apabila menggunakan hidden neuron yang lebih banyak. Setelah melihat semua error yang telah dihasilkan dari 5 kali percobaan menggunakan input, hidden neuron, dan output yang sama, error terkecil yang dihasilkan ada pada input 12 , hidden neuron 28, dan output 1 dengan nilai MAPE sebesar $12,59 \%$.

\section{KESIMPULAN DAN SARAN}

\section{A. Kesimpulan}

Berdasarkan hasil penelitian dan analisis untuk penentuan error dengan metode Neural Network yang telah dilakukan, maka dapat disimpulkan beberapa hal sebagai berikut :

1. Pola yang didapat mengenai bulan-bulan yang berpotensi terjadi DBD dimulai dari bulan Desember, terus meningkat ke bulan Januari, kemudian menurun di bulan Februari hingga Maret. Selanjutnya, di bulan April mulai menurun potensi terjadinya DBD dengan jumlah korban yang semakin menurun.

2. Penghitungan error menggunakan Neural Network (setelah 5 kali percobaan) didapatkan dengan menggunakan input layer 12 , hidden neuron 28, dan output layer 1 serta error yang didapatkan $12,59 \%$.

B. Saran

1. Peramalan dapat kembali dilakukan dengan menggunakan data historis yang lebih banyak sehingga dapat dilihat nilai peramalan dalam jangka waktu yang lebih panjang.

2. Pada Neural Network, dapat digunakan trial and error dari parameter-parameter yang diperlukan seperti perubahan hidden layer, hidden neuron, learning rate, momentum, fungsi aktivasi atau bahkan penambahan variabel independent lain agar hasilnya dapat lebih bervariasi.

\section{DAFTAR PUSTAKA}

[1] Assauri, S. (2004). Manajemen Pemasaran. Jakarta : PT. Raja Grafindo Persada.

[2] Dedi, R. (2011). Analisa Data Runtun Waktu. Yogyakarta : Penerbit ANDI.

[3] Heizer, J., \& Barry, R. (2006). Manajemen Operasi (Ketujuh). Jakarta : Salemba Empat.

[4] Jong Jek, S. (2005). Jaringan Syaraf Tiruan dan Pemrogramannya Menggunakan Matlab. Yogyakarta : Penerbit ANDI.

[5] Sukowati, S. (2010). Masalah Vektor Demam Berdarah Dengue (DBD) dan Pengendaliannya di Indonesia. Buletin Jendela Epidemiologi, Volume 2, 26-30. 